\title{
Ghrelin and pre-proghrelin immunoreactive cells in gastric neuroendocrine tumors associated with atrophic body gastritis
}

\author{
Grelina e pré-progrelina em tumores neuroendócrinos do estômago associados à gastrite atrófica do corpo
}

Letícia Figueiredo Moreira'; Maria Risoleta Nascimento Vieira Carvalho²; Alfredo José Afonso Barbosa ${ }^{3}$

key words
Neuroendocrine tumor
Gastric carcinoid
Ghrelin
Pre-proghrelin
Atrophic gastritis
Endocrine hyperplasia

\section{abstract}

Introduction: Ghrelin is a 28 amino acid peptide secreted mainly by endocrine cells present in the gastric mucosa and acknowledged as an endogenous releaser of growth hormone. The immunohistochemical expression of ghrelin has been described in neuroendocrine tumors, and it is believed that may exert modulating action related to the growth of these tumors. Objective: To study the presence of ghrelin and preproghrelin immunoreactive cells in gastric neuroendocrine tumors associated with atrophic body gastritis. Methods: Endoscopic biopsies from 15 patients with neuroendocrine tumor of the gastric mucosa associated with atrophic body gastritis were performed for immunohistochemistry, and specific chromogranin, ghrelin and preproghrelin antibodies were applied. The immunohistochemical expression was assessed in tumor cells and endocrine micronodular hyperplasia present in mucosa adjacent to the tumor, and it was classified in relation to the number of stained cells. Results: Chromogranin was positive in 14 out of 15 tumors. Ghrelin and preproghrelin immunoreactive cells were detected in 11 (73\%) and 13 (87\%) tumors, respectively. There was a significant correlation between the immunohistochemical results of both antigen expressions ( $k a p p a=$ $81 \%)$. Ghrelin and preproghrelin expression was detected in hyperplastic nodules present in the mucosa adjacent to the tumor in seven and eight cases, respectively. There was no correlation between these results and those observed in neoplastic cells. Conclusion: Ghrelin and preproghrelin immunoreactive cells may be found in variable number in Type I neuroendocrine gastric tumors and in hyperplastic nodules associated with these tumors. However, it remains unclear what role these peptides play on the development of these tumors.

\section{resumo}

Introdução: Grelina é um peptídeo de 28 aminoácidos, reconhecido como liberador endógeno do hormônio do crescimento, sendo secretado principalmente por células endócrinas da mucosa gástrica. A expressão imuno-histoquímica da grelina tem sido descrita em tumores neuroendócrinos, acreditando-se que possa ter ação moduladora relacionada com o crescimento desses tumores. Objetivo: Estudar a presença de células imunorreativas a grelina e pré-progrelina em tumores neuroendócrinos gástricos associados à gastrite crônica atrófica do corpo. Métodos: Biópsias endoscópicas de 15 pacientes portadores de tumor neuroendócrino da mucosa gástrica, associados à gastrite crônica atrófica do corpo, foram obtidas para as colorações imuno-histoquímicas, utilizando-se anticorpos contra cromogranina, grelina e pré-progrelina. A expressão imuno-histoquímica foi avaliada nas células tumorais e na hiperplasia endócrina micronodular presente na mucosa adjacente ao tumor e classificada em relação ao número de células coradas. Resultados: A cromogranina foi positiva em 14 dos 15 tumores. Células imunorreativas à grelina foram detectadas em 11 (73\%) tumores e à pré-progrelina em 13 (87\%), ocorrendo excelente concordância (kappa = 81\%) entre os resultados imuno-histoquímicos dos dois antígenos. A expressão de grelina e pré-progrelina foi detectada em nódulos hiperplásicos presentes na mucosa adjacente ao tumor em sete e oito casos, respectivamente, não ocorrendo concordância entre esses resultados e aqueles observados nas células neoplásicas. Conclusão: Células imunorreativas a pré-progrelina e grelina podem ser encontradas em número variável nos tumores neuroendócrinos tipo I do estômago e nas lesões hiperplásicas associadas a esses tumores. Entretanto, permanece obscuro o papel desses peptídeos em relação ao desenvolvimento desses tumores. unitermos

Tumor neuroendócrino

Carcinoide gástrico

Grelina

Pré-progrelina

Gastrite atrófica

Hiperplasia endócrina

1. Mestra em Patologia; docente de Patologia Ceral na Pontifícia Universidade Católica de Minas Cerais (PUC-MG).

2. Veterinária; estagiária no Laboratório de Patologia Digestiva e Neuroendócrina (LPDN) da Faculdade de Medicina da Universidade Federal de Minas Cerais (UFMG).

3. Doutor em Patologia; professor titular e responsável pelo LPDN da Faculdade de Medicina da UFMG; patologista do Instituto Alfa de Gastroenterologia. 


\section{Introduction}

Ghrelin, a 28-amino-acid peptide, predominantly displays strong growth hormone-releasing action mediated by the activation of growth hormone secretagogue receptor type $1 a^{(6,10,19)}$. First described about 10 years ago, it is known since then that it is secreted mainly by endocrine cells in the body of the stomach, which account for about $80 \%$ of plasma levels of this hormone ${ }^{(1,9)}$. A growing number of studies have indicated that ghrelin-immunereactive cells are present in smaller numbers in other organs ${ }^{(5,12,13)}$. Apart from stimulating growth hormone secretion ghrelin also stimulate appetite and positive energy balance ${ }^{(11)}$. It also presents actions on the hypothalamus and on the exocrine and endocrine pancreas, among other reported activities ${ }^{(22)}$. Ghrelin and obestatin, two products derived from posttranslational cleavage of the same precursor molecule named pre-proghrelin, are often present in the same neuroendocrine cell and seem to have antagonistic actions on energy balance and on gastrointestinal functions ${ }^{(21)}$. In the gastric mucosa of rats the obestatin- and pre-proghrelin-immunoreactive cells seem to be more frequent than those that express ghrelin and the precursor molecule ${ }^{(23)}$. This indicates that different tissues may provide a differentiated precursor cleavage molecule.

Endocrine cells that express ghrelin have been described in neuroendocrine tumors from different tissues ${ }^{(14)}$. Type I gastric neuroendocrine tumors have an indolent course and are believed to originate from hyperplasic nodules, common in atrophic body gastritis ${ }^{(20)}$. Often, these patients have hypergastrinaemia, supposedly the main stimulus for the appearance of the hyperplasic lesions and their progression to neuroendocrine tumor. However, the boundaries between the biological behavior of the hyperplasic and neoplasic state remain largely unknown.

Since ghrelin has been considered to be modulator of multiple endocrine functions including tumor cell proliferation, the aim of this work was to study its presence, as well as the precursor pre-proghrelin molecule, in gastric type I neuroendocrine tumors and in nodular hyperplasia present in gastric mucosa adjacent to the tumor.

\section{Methods}

For this study paraffin blocks of endoscopic biopsies from 15 patients with well-differentiated neuroendocrine tumor of the gastric mucosa associated with atrophic body gastritis (ABG) have been obtained from the Alfa Institute of Gastroenterology from Federal University of Minas Gerais (UFMG), Belo Horizonte, Brazil. The hematoxylin and eosin slides of each case were re-examined and the previous histological diagnoses were confirmed. New $4 \mu \mathrm{m}$ thick paraffin sections were obtained and used for immunohistochemical staining performed after antigen retrieval; this last step was performed by pretreatment of histological sections in antigen retrieval solution (citrate buffer solution retrievel $\mathrm{pH}$ 6, Dako Laboratories, USA) in a water bath at $98^{\circ} \mathrm{C}$ for 20 minutes and subsequent cooling at room temperature.

For immunohistochemical reactions the following primary antibodies were used: monoclonal antibodies against chromogranin A (Novocastra Laboratories, UK) to confirm the neuroendocrine nature of the tumors and polyclonal antibodies raised in rabbits against human ghrelin and pre-proghrelin (Phoenix Pharmaceuticals, USA). The degree of immunohistochemical expression of positive cells in tumor, and in nodular endocrine hyperplasia adjacent to the tumor was evaluated semi-quantitatively and classified as + (few stained cells, or $<10 \%) ;++$ (moderate number of stained cells, $10 \%$ to $50 \%$ ), and +++ (numerous stained cells, or $>50 \%)$. Although different histological types of hyperplastic proliferation of neuroendocrine cells in $A B G$ have been described only the nodular hyperplasia was considered for the objective of the present work ${ }^{(20)}$.

The agreement between the different immunohistochemical results were subjected to the kappa coefficient considering the following cutoffs: kappa $\leq 40 \%$ weak agreement; kappa $>40 \%$ to $<75 \%$ good or fair agreement; kappa $\geq 75 \%$ excellent agreement. This study was approved by the Ethics Committee of the UFMG, Brazil.

\section{Results}

Among the patients studied, nine (60\%) were female and six (40\%) were male. The average age of male patients ( $50 \pm 10$ years) was lower than that of ( $63 \pm 13$ years) female patients (Table 1).

Comparison of mean age in relation to sex

Table 1 in 15 patients with gastric neuroendocrine tumor type I

\begin{tabular}{ccccc}
\hline Sex & $n$ & $\begin{array}{c}\text { Average } \\
\pm \text { sd }\end{array}$ & $\begin{array}{c}\text { Statistic } \\
\text { test }\end{array}$ & $p$ \\
Female & 9 & $63 \pm 13$ & $t=2.13$ & 0.0544 \\
Male & 6 & $50 \pm 10$ & & \\
\hline
\end{tabular}

sd: standard deviation 
The histological pattern of the 15 tumors was similar in all of them, showing cells with regular, round nuclei, forming cords and small nests, immersed in the lamina propria, often occupying the full mucosa thickness, and infiltrating and destroying gastric crypts. Infiltration of muscularis mucosa occurred in most of the examined samples of tumors with or without infiltration of the submucosa (Figure 1). The neuroendocrine marker chromogranin was positive in 14 out of the 15 tumors studied. The one negative tumor for chromogranin, corresponding to the patient n. 10, subsequently showed positive immunoreactivity to antibodies against synaptophysin confirming its neuroendocrine nature (Table 2).

The immunohistochemical expression of ghrelin was present in $11(73 \%)$, and pre-proghrelin in $13(87 \%)$ neuroendocrine tumors and the degree of positivity of the immunoreactive cells was similar between these two peptides, showing excellent concordance for the presence of these two antigens in samples of the tumors (Table 3).

However, no significant correlation was seen between the results of immunostaining for chromogranin and ghrelin, as it was between chromogranin and pre-proghrelin. In almost all the tumors the chromogranin staining pattern

Table 2 pre-proghrelin

Distribution of the patients with gastric
neuroendocrine tumor type I according
to sex, age and immunohistochemical
expression of chromogranin, ghrelin and

\begin{tabular}{cccccc}
\hline & & \multicolumn{5}{c}{ Neuroendocrine tumor } \\
Patient & Sex & Age & Chromogranin Ghrelin & $\begin{array}{c}\text { Pre- } \\
\text { proghrelin }\end{array}$ \\
1 & M & 63 & + & + & + \\
2 & F & 73 & + & + & + \\
3 & M & 43 & + & + & + \\
4 & M & 42 & + & + & + \\
5 & F & 67 & + & - & + \\
6 & M & 56 & + & + & + \\
7 & F & 75 & + & - & - \\
8 & F & 55 & + & + & + \\
9 & F & 44 & + & - & + \\
$10^{*}$ & F & 83 & - & + & + \\
11 & M & 57 & + & - & - \\
12 & F & 49 & + & + & + \\
13 & F & 71 & + & + & + \\
14 & M & 39 & + & + & + \\
15 & F & 55 & + & + & + \\
\hline
\end{tabular}

M: male; F: female.

*Tumor positive for synaptophysin.

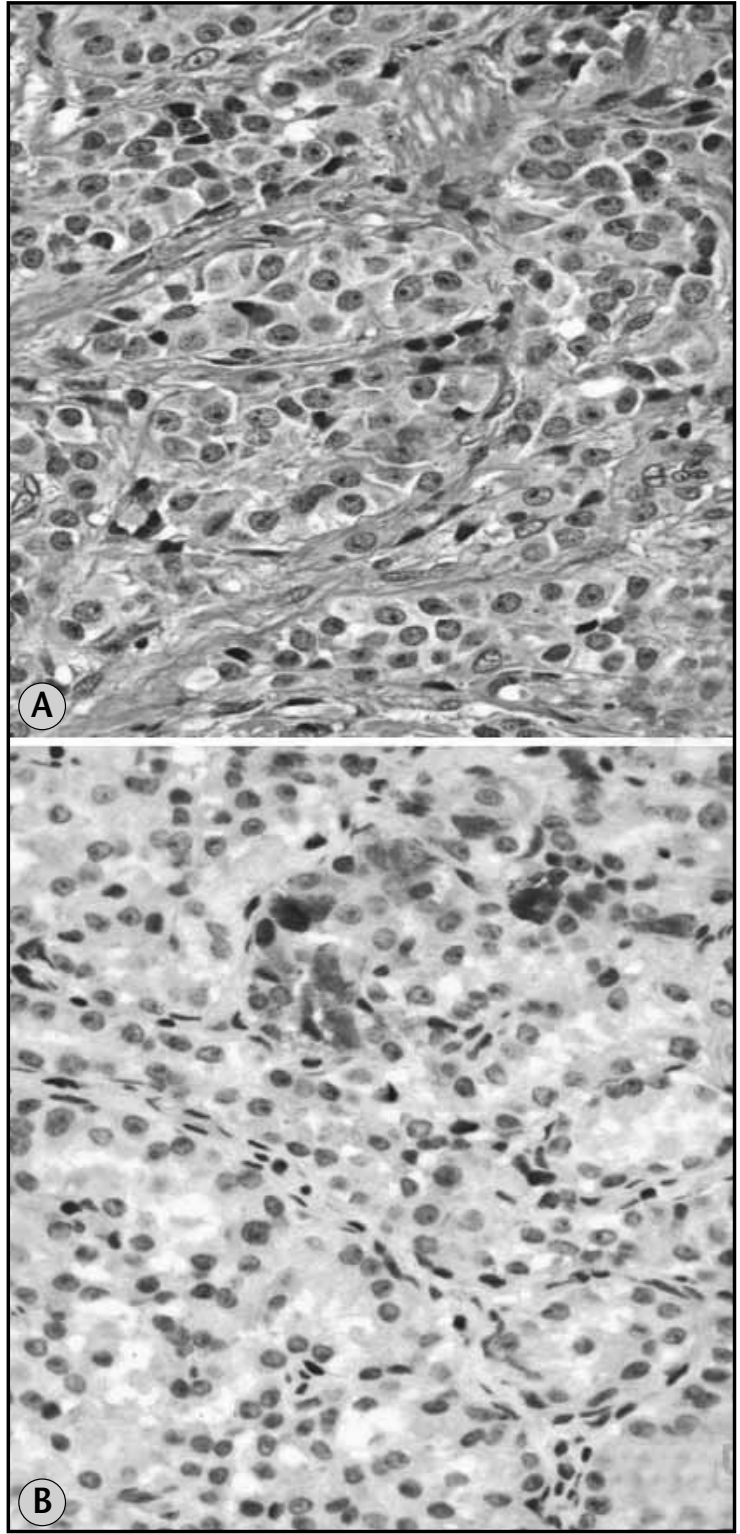

Figure 1 - Microscopic view of well differenciated gastric neuroendocrine tumor. (A) Hematoxylin and eosin staining (400x); (B) few ghrelin immunoreactive cells (400x)

Table 3 neuroendocrine tumor

Study of correlation between the degree of immunohistochemical reaction for ghrelin and pre-proghrelin in $\mathbf{1 5}$ gastric type I

\begin{tabular}{lccccc|}
\hline \multirow{5}{*}{ Ghrelin } & - & + & ++ & +++ & Total \\
- & 2 & 1 & 1 & 0 & 4 \\
+ & 0 & 6 & 0 & 0 & 6 \\
++ & 0 & 0 & 1 & 0 & 1 \\
+++ & 0 & 0 & 0 & 4 & 4 \\
\hline
\end{tabular}

Degree of immunostained cells: $+=<10 \% ;++=10 \%$ to $50 \%$;

$+++=>50 \%$; kappa $=81 \%$. 
was predominantly diffuse while the presence of ghrelin and pre-proghrelin positive cells varied in each case (Tables 4 and 5) (Figure 2).

The expression of ghrelin immunoreactive cells in the hyperplasic nodules was observed in seven (47\%) and preproghrelin in eight (53\%) cases (Tables 6 and 7).

Table 4

Study of correlation between the degree of
immunohistochemical reaction for ghrelin
and chromogranin in 15 gastric type I

\begin{tabular}{lccccc}
\hline & \multicolumn{5}{c}{ Chromogranin } \\
Ghrelin & - & + & ++ & +++ & Total \\
- & 0 & 0 & 0 & 4 & 4 \\
+ & 1 & 0 & 1 & 4 & 6 \\
++ & 0 & 0 & 0 & 1 & 1 \\
+++ & 0 & 0 & 0 & 4 & 4 \\
Total & 1 & 0 & 1 & 13 & 15 \\
\hline
\end{tabular}

Degree of immunostained cells: $+=<10 \% ;++=10 \%$ to $50 \%$; $+++=>50 \% ; \mathrm{kappa}=2 \%$.

Study of correlation between the degree

of immunohistochemical reaction for chromogranin and pre-proghrelin in 15

Table 5 gastric type I neuroendocrine tumors

\begin{tabular}{lccccc}
\hline \multicolumn{5}{c}{ Chromogranin } \\
Pre-proghrelin & - & + & ++ & +++ & Total \\
- & 0 & 0 & 0 & 2 & 2 \\
+ & 1 & 0 & 1 & 5 & 7 \\
++ & 0 & 0 & 0 & 2 & 2 \\
+++ & 0 & 0 & 0 & 4 & 4 \\
Total & 1 & 0 & 1 & 13 & 15 \\
\hline
\end{tabular}

Degree of immunostained cells: $+=<10 \%$; $++=10 \%$ to $50 \%$; $+++=>50 \%$; kappa $=2 \%$.

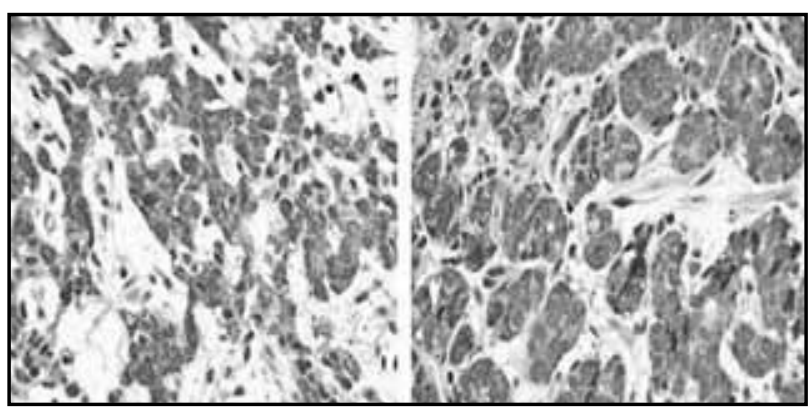

Figure 2 - Microscopic view of well differenciated gastric neuroendocrine tumor: immunohistochemical staining showing numerous ghrelin (A) and pre-proghrelin (B) immunoreactive cells. A and B 400x
Ghrelin immunoreactive cells in 15 type I gastric neuroendocrine tumors and in the

Table 6 hyperplasic nodules of adjacent mucosa

Ghrelin in neuroendocrine tumors

\begin{tabular}{llllll}
$\begin{array}{l}\text { Ghrelin in } \\
\text { hyperplastic } \\
\text { nodules }\end{array}$ & - & + & ++ & +++ & Total \\
Negative & 3 & 4 & 0 & 1 & 8 \\
Positive & 1 & 2 & 1 & 3 & 7 \\
\hline
\end{tabular}

Degree of immunostained cells: $+=<10 \%$; $++=10 \%$ to $50 \%$; $+++=>50 \%$; kappa $=22 \%$.

Table 7

Pre-proghrelin immunoreactive cells in 15 type I gastric neuroendocrine tumors and in the hyperplasic nodules of adjacent

Pre-proghrelin in neuroendocrine tumors

Pre-proghrelin in $\quad-\quad+\quad++\quad++$ Total hyperplastic nodules

\begin{tabular}{llllll} 
Negative & 2 & 4 & 0 & 1 & 7 \\
Positive & 2 & 2 & 1 & 3 & 8 \\
\hline
\end{tabular}

Degree of immunostained cells: $+=<10 \% ;++=10 \%$ to $50 \%$;

$+++=>50 \%$; kappa $=4 \%$.

\section{Discussion}

The gastric neuroendocrine tumor type $I$ is associated with $A B G$, and this latter pathological condition, considered as predisposing to gastric carcinoids, has been diagnosed with relative frequency in the Alfa Institute of Gastroenterology ${ }^{(8)}$. Patients with ABG often have elevated serum gastrin, and the main source of gastrin is the $G$ cells located mainly in gastric antral mucosa of the stomach that is usually preserved in this pathological condition. The hypergastrinaemia is the result of progressive impairment of the parietal cells of these patients resulting in achlorhydria. The atrophic gastric mucosa of the body, however, is rich in endocrine cells, which persist despite the glandular atrophy, and hyperplastic endocrine proliferation frequently occurs during the evolution of the disease. It is recognized that endocrine hyperplasia would result mainly from stimulation of the hormone gastrin on enterochromaffin-like cells (ECL); however, one can not rule out other local and systemic stimuli as well as other types of endocrine cells participating of the hyperplasic changes of the endocrine cells in this pathological condition ${ }^{(3)}$. Finally, in a certain number of these patients, probably 
due to the presence of hyperplasic nodules, comes the neuroendocrine tumor, often multifocal and usually presenting an indolent course $\mathrm{e}^{(2)}$. No one knows exactly neither the factors responsible for the progression of these hyperplasic nodules into neoplasic nor the factors, besides the hormone gastrin, that modulate the growth of these tumors. Similarly, the morphological boundaries between these two conditions, hyperplasia and neoplasia, are not clear. The present study adopted as indicative of neoplasia the presence of enlarged nodules with at least $500 \mu \mathrm{m}$ in diameter with invasion and destruction of gastric cripts and infiltration of the muscularis mucosa or submucosa. The presence of dysplasia usually does not provide parameters for accurate diagnosis because these tumors, regardless of their biological behavior, have fairly uniform cellularity. Ghrelin immunoreactive cells seems to be a common finding in neuroendocrine tumors not only from the stomach but also in other organs, such as pituitary, pancreas and thyroid ${ }^{(7,14)}$. However, it does not seem to occur in non-endocrine tumors, even in organs rich in ghrelin-producing cells as the stomach ${ }^{(15)}$. The fact that we frequently find neuroendocrine tumors containing a variable number of immunoreactive ghrelin cells does not indicate that this peptide is being released in significant quantities in the bloodstream. As far as we know, only one case of pancreatic neuroendocrine tumor, with numerous immunoreactive ghrelin cells, was reported to be associated with high levels of plasma ghrelin ${ }^{(4)}$. In the present study the immunohistochemical expression of ghrelin was observed in 11 (73.3\%) among the 15 gastric neuroendocrine tumors studied. Therefore, as observed by other authors, a significant number of these tumors contain ghrelin immunoreactive cells. It should be noted that the number of immunoreactive cells varied in relation to the different tumors that express this peptide, i. e., six $(55 \%)$ of them have only a few cells $(<10 \%)$ positive for ghrelin, while in four (36\%) tumors this occurred in more than $50 \%$ of the neoplasic tissue. In fact, in a substantial proportion (27\%) of 15 studied tumors the presence of ghrelin immunoreactive cells has not been observed. The frequency of findings of ghrelin immunoreactive cells in the present study is very close to the results reported by Papotti et al.(16). These authors found 12 (75\%) ghrelin positive cases in 16 gastric carcinoids studied. Likewise, this finding is similar to that observed by Rindi et al. who found ghrelin immunoreactive cells in 25 (76\%) out of 33 well-differentiated neuroendocrine tumors of the stomach. It should be noted that in the latter study only 21 (64\%) of tumors were type I gastric carcinoid and the others were types II and III ${ }^{(17,18)}$.

Since nodular hyperplasia observed in patients with $A B C$ is believed to be a precursor lesion of gastric neuroendocrine tumors it would also be of interest to do a comparative study between ghrelin and pre-proghrelin immunoreactivity in these hyperplasic nodules. The presence of these nodules containing ghrelin immunoreactive cells occurred just in seven, and pre-proghrelin in eight out of the 15 tumors of the present series. Therefore, in seven tumors nodular hyperplasia did not present immunoreactivity to ghrelin and pre-proghrelin. Therefore, there seems to be no statistical correlation between the immunohistochemical expression of ghrelin and pre-proghrelin in both tumors and hyperplasic nodules.

\section{Conclusion}

In conclusion, one can assume that both ghrelin and preproghrelin immunoreactive cells may be found frequently, and with similar proportions, in type I gastric neuroendocrine tumors, and in endocrine hyperplasia associated with them. Because of the wide spectrum of endocrine and paracrine actions of ghrelin, one can also hypothesize that somehow this peptide may be involved in the pathogenesis and development of type I gastric neuroendocrine tumors and of its associated hyperplasic lesions.

\section{Acknowledgements}

We are indebted to Eugênio M. A. Goulart for excellent technical assistance in estatistics.

\section{References}

1. ABIKO, Y. et al. Enhanced plasma ghrelin levels in Helicobacter pylori-colonized, interleukin-1-receptor type 1-homozygous knockout (IL-1R1-/-) mice. World J Gastroenterol, v. 11, n. 27, p. 4148-53, 2005.
2. ANNIBALE, B. et al. Atrophic body gastritis patients with enterochromaffin-like cell dysplasia are at increased risk for the development of type I gastric carcinoid. Eur J Gastroenterol Hepatol, v. 12, n. 12, p. 1449-56, 2001. 
3. BORDI, C. et al. Endocrine cell growths in atrophic body gastritis. Critical evaluation of a histological classification. J Pathol, v. 182, n. 3, p. 339-46, 1997.

4. CORBETTA, S. et al. Circulating ghrelin levels in patients with pancreatic and gastrointestinal neuroendocrine tumors: indentification of one pancreatic ghrelinoma. J Clin Endocrinol Metab, v. 88, n. 7, p. 3117-20, 2003.

5. DATE, Y. et al. Ghrelin, a novel growth hormone-releasing acylated peptide, is synthesised in a distinct endocrine cell type in the gastrointestinal tracts of rats and humans. Endocrinology, v. 141, p. 4255-61, 2000.

6. HOWARD, A. D. et al. A receptor in pituitary and hypothalamus that functions in growth hormone release. Science, v. 273, p. 974-7, 1996.

7. IWAKURA, H. et al. Ghrelin expression in islet cell tumors: augmented expression of ghrelin in a case of glucagonoma with multiple endocrine neoplasm type I. J Clin Endocrinol Metab, v. 87, p. 4885-8, 2002.

8. KAKEHASI, A. M. et al. Chronic gastritis and bone mineral density in women. Dig Dis Sci, v. 54, p. 819-24, 2009.

9. KOJIMA, M. et al. Ghrelin is a growth-hormone-releasing acylated peptide from stomach. Nature, v. 402, p. 656-60, 1999.

10. KOJIMA, M.; HOSODA, H.; KANGAWA, K. Purification and distribution of ghrelin: the natural endogenous ligand for the $\mathrm{GH}$ (growth hormone) secretagogue receptor. Horm Res, v. 56, Suppl, p. 93-7, 2001.

11. KORBONITS, M. et al. Ghrelin: a hormone with multiple functions. Front Neuroendocrinol, v. 25, p. 27-68, 2004.

12. KORBONITS, M. et al. Presence of ghrelin in normal and adenomatous human pituitary. Endocrine, v. 14, p. 101-4, 2001.

13. KORBONITS, M. et al. The expression of the GHS receptor ligand ghrelin in normal and abnormal human pituitary and other NE tumors. J. Clin Endocrinol Metab, v. 86, n. 2, p. 881-7, 2001.

14. LEONITIOU, C. A. et al. Ghrelin in neuroendocrine organs and tumours. Pituitary, v. 10, n. 3, p. 213-25, 2007.

15. MOTTERSHEAD, M. et al. Immunohistochemical and quantitative mRNA assessment of ghrelin expression in gastric and oesophageal adenocarcinoma. J Clin Pathol, v. 60, n. 4, p. 405-9, 2007.

16. PAPOTTI, M. et al. Grelin-producing endocrine tumors of the stomach and intestine. J Clin Endocrinol Metab, v. 86, n. 10, p. 5052-9, 2001.

17. RINDI, G. et al. Characterization of gastric ghrelin cells in man and other mammals: studies in adult and fetal tissues. Histochem Cell Biol, v. 117, p. 511-9, 2002.

18. RINDI, G. et al. Ghrelin expression in gut endocrine growths. Histochem Cell Biol, v. 117, n. 6, p. 521-5, 2002.

19. SMITH, R. G.; LEONARD, R. GH secretagogue receptor family members and ligands. Endocrine, v. 14 , n. 1, p. 9-14, 2001.

20. SOLCIA, E. et al. Histopathological classification of nonantral gastric endocrine growths in man. Digestion, v. 41 , p. $185-200,1988$.

21. ZHANG, J. V. et al. Obestatin, a peptide encoded by the ghrelin gene, opposes ghrelin's effests on food intake. Science, v. 310, p. 996-9, 2005.

22. ZHANG, W. et al. Inibition of pancreatic protein secretion by ghrelin in the rat. J Physiol, v. 537, p. 231-6, 2001.

23. ZHAO, C-M. et al. Characterization of obestatin- and ghrelin-producing cells in the gastrointestinal tract and pancreas of rats: an immunohistochemical and electron-microscopic study. Cell Tissue Res, v. 331, p. $575-87,2008$. 